\title{
Fenhexamid Resistance in Botrytis cinerea from Strawberry Fields in the Carolinas Is Associated with Four Target Gene Mutations
}

Anja Grabke, Dolores Fernández-Ortuño, and Guido Schnabel, School of Agricultural, Forest and Environmental Sciences, Clemson University, Clemson SC 29634

\begin{abstract}
Grabke, A., Fernández-Ortuño, D., and Schnabel, G. 2013. Fenhexamid resistance in Botrytis cinerea from strawberry fields in the Carolinas is associated with four target gene mutations. Plant Dis. 97:271-276.

Botrytis cinerea, the causal agent of gray mold disease, is one of the most important pathogens of strawberry. Its control in commercial strawberry fields is largely dependent on the application of fungicides during bloom and fruit maturation. The hydroxyanilide fenhexamid is one of the most frequently used fungicides in the southeast of the United States for gray mold control. It inhibits the 3-ketoreductase (Erg27) of the ergosterol biosynthesis pathway and, due to this sitespecific mode of action, is at risk for resistance development. Singlespore isolates were collected from 11 commercial strawberry fields in North and South Carolina and subjected to a conidial germination assay that distinguished sensitive from resistant phenotypes. Of the 214 isolates collected, $16.8 \%$ were resistant to fenhexamid. Resistance was found in three of four locations from North Carolina and in four of seven locations from South Carolina, indicating that resistance was

were associated with resistance, with F412S the predominant and most widespread mutation. In this study, mutations T63I and F412C in field isolates of $B$. cinerea are described for the first time. Detached fruit studies showed that field rates of Elevate 50 WDG (fenhexamid) controlled sensitive but not resistant isolates carrying any of the four mutations. Resistant isolates produced the same lesion size and number of sporulating lesions on fruit sprayed with Elevate $50 \mathrm{WDG}$ as on untreated controls, showing the fungicide's loss of efficacy against those isolates. A rapid polymerase chain reaction method was developed to quickly and reliably distinguish isolates sensitive or resistant to fenhexamid in the Carolinas and to determine the mutation associated with resistance. The presence of fenhexamid-resistant strains in $B$. cinerea from strawberry fields in the Carolinas must be considered in future resistance management practices for sustained gray mold control.
\end{abstract} widespread. Mutations in Erg27 (T63I, F412S, F412C, and F412I)
Gray mold is one of the most economically important diseases of cultivated strawberry (Fragaria $\times$ ananassa), and a significant threat to the United States' $\$ 2.4$ billion strawberry crop (22). In the southeastern United States, the disease is caused by Botrytis cinerea Pers. but berries can also be affected by B. caroliniana X.P. Li \& G. Schnabel sp. nov. (13,14,19). Crop losses resulting from gray mold disease are especially severe under moist weather conditions, and occur not only during the crop growing season but also after harvest and during storage and transit.

The control of gray mold in commercial strawberry fields is largely dependent on the application of fungicides during bloom and fruit maturation. Several site-specific fungicides with different modes of action are currently available for gray mold management, including anilinopyrimidines, benzimidazoles, dicarboximides, hydroxyanilides, quinone outside inhibitors (QoIs), phenylpyrroles, and succinate dehydrogenase inhibitors (SDHIs). However, effective control of gray mold is threatened due to the emergence of fungicide resistance. For example, $B$. cinerea from strawberry fields in California, North Carolina, and South Carolina has developed resistance to QoIs and SDHIs, indicating the emergence of resistance to site-specific fungicides $(12,20)$.

The hydroxyanilide fenhexamid is a site-specific fungicide with a broad activity spectrum that includes Botrytis spp. and related fungi such as Monilinia and Sclerotinia spp. $(23,26)$ and has become a key component of gray mold disease management in the

Corresponding author: G. Schnabel, E-mail: schnabe@ clemson.edu

Technical contribution number 6056 of the Clemson University Experiment Station.

Accepted for publication 4 September 2012.

http://dx.doi.org/10.1094/PDIS-06-12-0587-RE

(C) 2013 The American Phytopathological Society
United States. This fungicide specifically inhibits the 3-ketoreductase involved in the C-4 demethylation during ergosterol biosynthesis (8). Resistance to this fungicide was reported in $\mathrm{B} . \mathrm{ci}$ nerea isolates from North American grapevine, the herbaceous perennial Heuchera, and strawberry fruit in California and Germany $(16,20,21,24,27)$; however, it is unclear whether resistance has emerged on the east coast of the United States.

Four fenhexamid-resistant phenotypes named HydR1, HydR2, $\mathrm{HydR}^{-}$, and HydR $3^{+}$have been described in Botrytis field isolates $(1,2,15,18)$. Mycelium of isolates classified as HydR1 or HydR2 are able to grow in the presence of high or moderate levels of fenhexamid, respectively, but their germinating spores remain susceptible $(3,9,26)$. All HydR1 isolates were B. pseudocinerea from grapevine in France whereas HydR2 isolates were $B$. cinerea from France and Japan $(1,2,3,17)$. HydR3 isolates show moderate $\left(\mathrm{HydR}^{-}\right)$or high $\left(\mathrm{HydR}^{+}\right)$resistance during both mycelial growth and germ tube elongation $(1,2,15,18)$. Thus, HydR3 isolates are the greatest cause of concern for disease management and have been regularly found in commercial fields since $2004(1,11,15)$.

HydR3 phenotypes are associated with genetic modifications in the target gene erg27 resulting in alterations of the 3-ketoreductase (4). Several amino acid substitutions in $\operatorname{Erg} 27$ were reported in field isolates of $B$. cinerea conferring different levels of resistance to this fungicide. For example, HydR3 $3^{-}$isolates were found to contain point mutations in the erg 27 gene resulting in a variety of predicted amino acid changes (F26S, L195F, V309M, A314V, S336C, N369D, L400F/S, Y408S, R496T, and a deletion at P238) $(10,11,15)$. In HydR $3^{+}$isolates, alterations at amino acid positions 496 (T496R) and 412 (F412S, - V, or -I) were found $(1,15)$.

The objectives of this study were to (i) assess the occurrence and frequency of fenhexamid resistance in $B$. cinerea from commercial strawberry fields in North and South Carolina, (ii) identify mutations in the erg27 gene and potentially associated fitness penalties in resistant isolates, and (iii) develop a polymerase chain reaction (PCR) assay to identify mutations associated with fenhexamid resistance. 


\section{Materials and Methods}

Fungal isolates and culture conditions. In total, 214 singlespore isolates of $B$. cinerea obtained from strawberry fruit with gray mold symptoms in 2011 from commercial fields HP, MV, NC, and SBY in North Carolina and FLOR, GIK, JEY, KUD, MER, MOD, and WIC in South Carolina were used in this study. Fenhexamid was used in all locations, except for organic field WIC. The same collection minus two isolates from SBY and one isolate from MV was used in previous studies to characterize the isolates for QoI and SDHI resistance (12). Single-spore isolation was described by Fernández-Ortuño et al. (12). Mycelium of each isolate was stored at $-80^{\circ} \mathrm{C}$ in $80 \%$ (vol/vol) glycerol (Fisher Scientific).

Sensitivity of $B$. cinerea isolates to fenhexamid. A conidia germination assay using discriminatory doses of fenhexamid (Elevate $50 \mathrm{WDG}$; Arysta LifeScience) at 1 and $50 \mathrm{mg} / \mathrm{liter}$ was used to distinguish isolates with different levels of resistance to fenhexamid (28). For each isolate, a 40- $\mu$ l drop of spore suspension $(4 \times$ $10^{5}$ spores $/ \mathrm{ml}$ ) was streaked out across the length of a $1 \%$ malt extract agar plate amended with or without fungicide. After 12 to 14 $\mathrm{h}$ of incubation, the germ-tube growth of 50 conidia/isolate was visually assessed, using a microscope (OLYMPUS BX41TF; Olympus Optical Co. Ltd.). Isolates with a fully grown germ tube on 1 and $50 \mathrm{mg} / \mathrm{liter}$ were classified as resistant, whereas sensitive isolates displayed no germ-tube development. The lower dose was added to the screening to potentially identify isolates with low levels of resistance. This experiment was replicated three times. Determination of $50 \%$ effective concentration $\left(\mathrm{EC}_{50}\right)$ values for resistant isolates was not attempted because mycelium grew uninhibited at 50 $\mathrm{mg} / \mathrm{liter}$. Therefore, $\mathrm{EC}_{50}$ values can be considered $>50 \mathrm{mg} / \mathrm{liter}$.

Analysis of $\mathrm{erg} 27$ gene sequences from sensitive and resistant isolates. Genomic DNA was extracted from mycelia as previously described by Chi at al. (7). The oligonucleotides used in this study are listed in Table 1. The primer pair erg27Beg and erg27End was used to amplify the erg 27 gene from $B$. cinerea DNA. PCR reactions were performed in an iCycler Thermal Cycler (Bio-Rad Laboratories Inc.) in a final volume of $50 \mu \mathrm{l}$ containing $50 \mathrm{ng}$ of fungal template DNA, $10 \mathrm{pmol}$ of each primer, $2.5 \mathrm{mM}$ each dNTP, $5 \mu \mathrm{l}$ of $10 \times$ LA PCR buffer II, and $2.5 \mathrm{U}$ of Takara LA Taq Polymerase (Takara Bio Inc.). The following PCR run parameters were used: $3 \mathrm{~min}$ at $95^{\circ} \mathrm{C}$; followed by 40 cycles of $95^{\circ} \mathrm{C}$ for $30 \mathrm{~s}$, $60^{\circ} \mathrm{C}$ for $30 \mathrm{~s}$, and $68^{\circ} \mathrm{C}$ for $1.5 \mathrm{~min}$; with a final elongation at $68^{\circ} \mathrm{C}$ for $5 \mathrm{~min}$. PCR products were purified with the ExoSAP-IT PCR purification kit (USB Corporation, Cleveland) using the manufacturer's instructions and sequenced with the primers erg27Beg, erg27End, erg1800down, and erg2000up at the Clemson University Genomics Institute (Clemson, SC) using BigDye dyeterminator sequencing technology.

Development of the allele-specific PCR assays. Variations at amino acid positions 63 (T63I) and 412 (F412S/I/C) of Erg27 were observed in fenhexamid-resistant isolates. Primers were designed to screen for these amino acid variations (Fig. 1). Six primers (Ta-

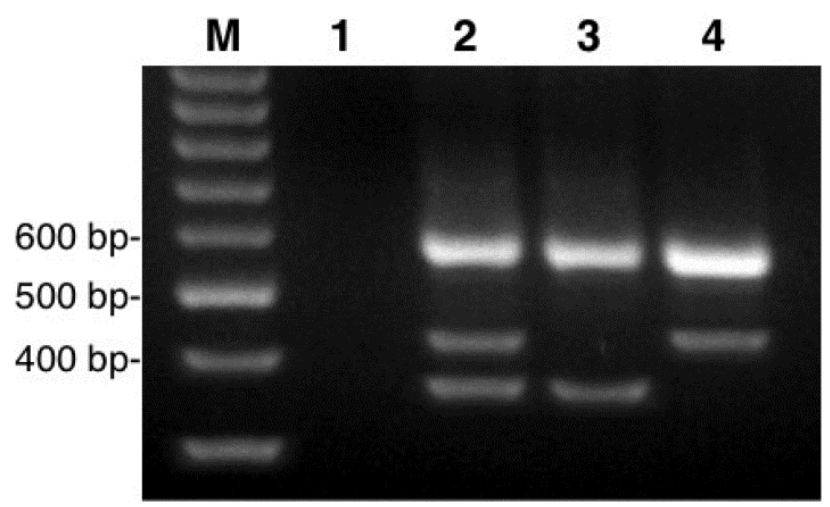

Fig. 2. Polymerase chain reaction (PCR) amplification of erg27 gene fragments with universal primers (T63_F, T63_R, F412_F, and F412_R) in combination with allele-specific primers T63_int and F412_int to distinguish between erg27 alleles. Lane 1, no template control; lanes 2-4, amplifications from isolates JEY7wild type SBY31F412S, and SBY27 ${ }^{\text {T63l; }}$ M, GeneRuler 100-bp DNA Ladder (Fermentas Inc.). PCR products were run on $1.8 \%$ agarose gels.

Table 1. Name, sequence, direction, and location of oligonucleotides in the erg 27 gene used in this study

\begin{tabular}{|c|c|c|c|c|}
\hline Name & Sequence $\left(5^{\prime}-3^{\prime}\right)$ & DNA strand direction & Location in the $\operatorname{erg} 27$ gene $\left(5^{\prime}-3^{\prime}\right)$ & Reference \\
\hline erg27Beg & TGGGATTACCACCATGGGAGACAAGTG & Forward & $2-28$ & 15 \\
\hline erg27End & CAATGGTTCCGCATTTCTTTGCCTCCC & Reverse & $1,556-1,582$ & 15 \\
\hline erg1800down & CCGCCACTTATTCCGCAGATGTT & Forward & $531-553$ & 15 \\
\hline erg2000up & TCGGAGGGTTTGGCTTGTTTTG & Reverse & $813-834$ & 15 \\
\hline T63_F & TGGGAGACAAGTGAGAGCCAG & Forward & $16-36$ & This article \\
\hline T63_int & CACCTCTGAAGACACGATTCACA & Forward & $246-268$ & This article \\
\hline T63_R & CGCCTTCAGACCCTTCCTTC & Reverse & $580-599$ & This article \\
\hline F412_F & GACATTACGTTCTCGCACACG & Forward & 918-938 & This article \\
\hline F412_int & CTTCCCATCCATCTTACAAGGTAGAA & Reverse & $1,313-1,338$ & This article \\
\hline F412_R & CAACCAGGAACTTCGGTTCG & Reverse & $1,484-1,503$ & This article \\
\hline F412S_int & СТTСССАТССАTСTTACAAGGTAGG & Reverse & $1,314-1,338$ & This article \\
\hline F412I_int & CTTCССATCCATCTTACAAGGTAGAT & Reverse & $1,313-1,338$ & This article \\
\hline F412C_int & СТTСССАТССАTСTTACAAGGTAGCA & Reverse & $1,313-1,338$ & This article \\
\hline
\end{tabular}

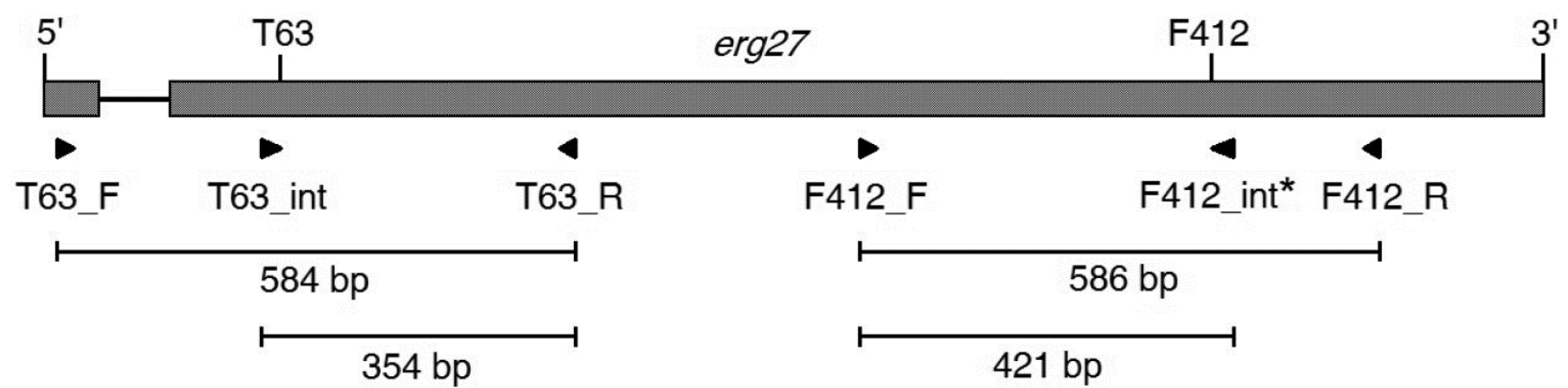

Fig. 1. Schematic representation of the phenotype-differentiating polymerase chain reaction (PCR) assay strategy distinguishing isolates sensitive and resistant to fenhexamid. Gray boxes indicate coding sequences of the erg27 gene, the line between represents the position of a single intron, and the primer locations and directions are indicated with black arrows. The star indicates the position of primers F412S_int, F412C_int, and F412I_int used for the F412 allele-specific PCR. 
ble 1) were used in a PCR cocktail to simultaneously screen for isolates with the T63 or F412 alterations. Primer pair T63_F and T63_R amplified a 584-bp fragment from all isolates and internal primer T63_int in combination with T63_R amplified a single 354bp fragment only from isolates carrying the T63 wild-type allele. F412_F and F412_R amplified a 586-bp fragment from all isolates but internal primer F412_int in combination with F412_F amplified a 421-bp fragment only from isolates carrying the F412 wildtype allele (Figs. 1 and 2). The 584- and 586-bp amplicons appeared as a single band for all isolates after electrophoresis on the agarose gel, due to their size similarities (Fig. 2). The larger fragments verified the functionality of the PCR assay in the potential absence of the 354- and 421-bp fragments, which could occur if an isolate possessed nucleotide variations at both amino acid positions (63 and 412). PCR reactions were performed in a final volume of 50 $\mu \mathrm{l}$ containing $50 \mathrm{ng}$ of fungal template DNA; 10 pmol of primers F412_F, F412_int, T63_R and T63_int; 6 pmol of primers F412_R and T63_F; $2.5 \mathrm{mM}$ each dNTP; $5 \mu \mathrm{l}$ of $10 \times$ LA PCR buffer II; and $2.5 \mathrm{U}$ of Takara LA Taq Polymerase (Takara Bio Inc.). PCR was conducted with an initial preheating for $3 \mathrm{~min}$ at $95^{\circ} \mathrm{C}$; followed by 40 cycles of $94^{\circ} \mathrm{C}$ for $30 \mathrm{~s}, 64^{\circ} \mathrm{C}$ for $30 \mathrm{~s}$, and $68^{\circ} \mathrm{C}$ for $35 \mathrm{~s}$; with a final elongation at $68^{\circ} \mathrm{C}$ for $5 \mathrm{~min}$. The PCR products were separated on ethidium-bromide-stained 1.8\% (wt/vol) agarose gels (Thermo Scientific) in $1 \times$ Tris-borate-EDTA and exposed to UV-light to visualize DNA fragments. Taq DNA Polymerase (New England BioLabs) can be used instead of Takara LA Taq Polymerase if the six-primer PCR is done in two steps (data not shown). The first detects the F412 mutations with primers F412_int, F412_F, and F412_R and the second detects the T63 mutations with primers T63_int, T63_F, and T63_R. Then, each PCR needs to be conducted with a slightly changed protocol: $3 \mathrm{~min}$ at $95^{\circ} \mathrm{C}$; followed by 35 cycles of $94^{\circ} \mathrm{C}$ for $30 \mathrm{~s}, 63^{\circ} \mathrm{C}$ for $30 \mathrm{~s}$, and $72^{\circ} \mathrm{C}$ for $40 \mathrm{~s}$; with final elongation at $72^{\circ} \mathrm{C}$ for $5 \mathrm{~min}$ (data not shown).

A second assay (F412 allele-specific PCR) was designed to distinguish between the F412S, F412C, and F412I mutations. Primers F412_F and F412_R were used in combination with internal primer F412S_int, F412C_int, or F412I_int to detect the F412S, F412C, and F412I mutations, respectively (Fig. 1). For each isolate, reactions with each of the three allele-specific primers was performed. The PCR conditions were the same as described above, except that 10 pmol of each primer was used.

Detached fruit assay. Commercially grown, mature but still firm strawberry fruit were rinsed with sterile water three times for $30 \mathrm{~s}$ each and allowed to air dry. The dried fruit were placed into plastic boxes (eight strawberry fruit per box for each of three replicates per treatment) and sprayed $4 \mathrm{~h}$ prior to inoculation with Elevate $50 \mathrm{WDG}$ at $3.6 \mathrm{~g} /$ liter to runoff using a hand mister. Untreated fruit were sprayed with distilled sterile water. The fruit was again allowed to dry for $4 \mathrm{~h}$ at 20 to $22^{\circ} \mathrm{C}$ before each fruit was stabbed at three equidistant points to a depth of $9.5 \mathrm{~mm}$ using a $26 \mathrm{G} 3 / 8$ 9.5-mm beveled syringe tip (Becton Dickson \& Co.). Immediately thereafter, the wounds were inoculated with a $30 \mu$ l-droplet of conidia suspension prepared in distilled, sterile water $\left(10^{6}\right.$ spores $/ \mathrm{ml}$ ). Untreated strawberry fruit inoculated with sterile water were used as negative control. After inoculation, the boxes were wrapped in plastic bags to keep the relative humidity at 98 to $100 \%$ and kept at $22^{\circ} \mathrm{C}$ for $24 \mathrm{~h}$. After that, the fruit were uncovered and disease incidence was scored after 4 days visually by assessing the presence or absence of gray mold signs and symptoms. The diameter of the lesions was measured with a standard ruler to the nearest millimeter. The entire experiment was replicated twice.

Data analysis. A statistical model was developed that related the detached fruit assay responses (percent sporulating lesions and lesion size) to the experimental factors of experimental replication, isolate, fungicide treatment, and their combination. The method of least squares was used to estimate the model terms associated with the factors, and analysis of variance was used to test for a significant effect of the factors on the response means. If a factor was found to be significant, mean separation (using Student's $t$ test) was used to further determine the nature of the effect of the factor on the responses. All calculations were performed using the statistical package JMP (version 9.0.0; SAS Institute Inc.) and all tests were performed with $\alpha=0.05$.

\section{Results}

Sensitivity of $\boldsymbol{B}$. cinerea isolates to fenhexamid. Among the 214 field isolates, $36(17 \%)$ were resistant to fenhexamid and grew at 1 and $50 \mathrm{mg} / \mathrm{liter}$. Resistance was found in three of four locations from North Carolina and in four of seven locations from South Carolina, indicating that resistance was widespread but may not have been present in every location. The highest percentage of resistant isolates was obtained from location SBY (54\%) in North Carolina. At all other locations, 33\% or fewer isolates were resistant (Table 2; Fig. 3).

Amino acid sequence variations in the $\operatorname{erg} 27$ gene of fenhexamid-resistant isolates. Because amino acid changes in the Erg27

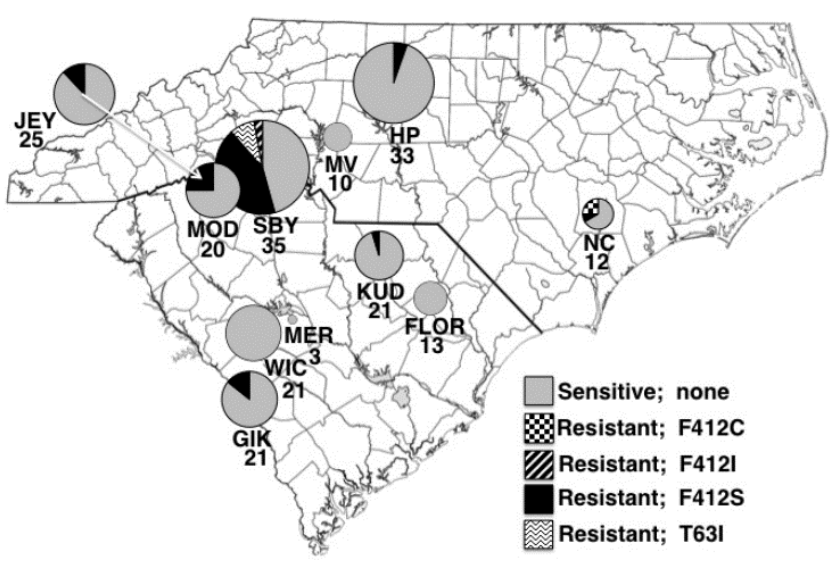

Fig. 3. Occurrence and frequency of Erg27 amino acid genotypes associated with resistance to fenhexamid in Botrytis cinerea isolates from the Carolinas. Sensitive isolates are represented in gray and resistant isolates with mutations F412C, F412I, F412S, and T63l are represented with checker board, black and white stripes, solid black, and waived lines, respectively. Circle diameters correspond to the number of isolates collected in each location, which is indicated below the location's name. The white arrow indicates the center position of the JEY circle.

Table 2. Sensitivity to fenhexamid and presence or absence of mutations in the 3-ketoreductase (Erg27) of Botrytis cinerea isolates collected in North and South Carolina

\begin{tabular}{|c|c|c|c|}
\hline Isolates & $\begin{array}{c}\text { Number } \\
\text { of isolates }\end{array}$ & $\begin{array}{l}\text { Fenhexamid } \\
\text { sensitivity }\end{array}$ & $\begin{array}{l}\text { Erg27 } \\
\text { alteration }\end{array}$ \\
\hline $\begin{array}{l}\text { FLOR1-13, GIK1-9, GIK13-21, HP1-15, HP17-32, HP34, JEY1-4, JEY6-16, JEY18-23, JEY25, KUD1-9, } \\
\text { KUD11-21, MER1-3, MOD1-10, MOD12, MOD14, MOD17-18, MOD20, MV1-5, MV7-11, NC1-4, }\end{array}$ & & & \\
\hline NC8-11, SBY1, SBY4-5, SBY7-9, SBY12, SBY15, SBY17-19, SBY23-25, SBY28-29, WIC1-21 & 178 & $\mathrm{~S}$ & None \\
\hline SBY10, SBY21, SBY27 & 3 & $\mathrm{R}$ & T63I \\
\hline NC6-7, NC12 & 3 & $\mathrm{R}$ & $\mathrm{F} 412 \mathrm{C}$ \\
\hline SBY20 & 1 & $\mathrm{R}$ & F412I \\
\hline $\begin{array}{l}\text { GIK10-12, HP16, JEY5, JEY17, JEY24, KUD10, MOD11, MOD13, MOD15-16, MOD19, NC5, SBY2, } \\
\text { SBY6, SBY11, SBY13-14, SBY22, SBY26, SBY30-37 }\end{array}$ & 29 & $\mathrm{R}$ & $\mathrm{F} 412 \mathrm{~S}$ \\
\hline
\end{tabular}

${ }^{\mathrm{z}} \mathrm{S}=$ sensitive; $\mathrm{R}=$ resistant. Isolate sensitivity was assessed according to Weber and Hahn (28). 
protein had previously been associated with fenhexamid resistance, we sequenced the majority of the $\operatorname{erg} 27$ gene from three fenhexamid-sensitive (GIK1, MV4, and NC11) and one fenhexamidresistant (SBY11) isolate. A change from TTC to TCC in codon 412 was present in the resistant isolate, resulting in the replacement of phenylalanine with serine (F412S). The remaining resistant isolates were screened for the F412S allele by PCR (data not shown) and, although most of the isolates possessed the F412S allele, seven did not. Sequencing of erg27 from these seven isolates revealed additional mutant alleles. In three isolates (SBY10, SBY21, and SBY27) a change from ACA to ATA was found in codon 63, causing a substitution of isoleucine for threonine (T63I). The other four isolates had mutations in codon 412 (TTC to TGC or ATC), resulting in an amino acid change from phenylalanine to cysteine (F412C; isolates $\mathrm{NC6}, \mathrm{NC7}$, and $\mathrm{NC12}$ ) or isoleucine (F412I; isolate SBY20), respectively. One amino acid variation at position 238 (substitution of proline by serine) was subject to change in resistant and sensitive isolates and, thus, did not correlate with resistance. The four different alleles associated with

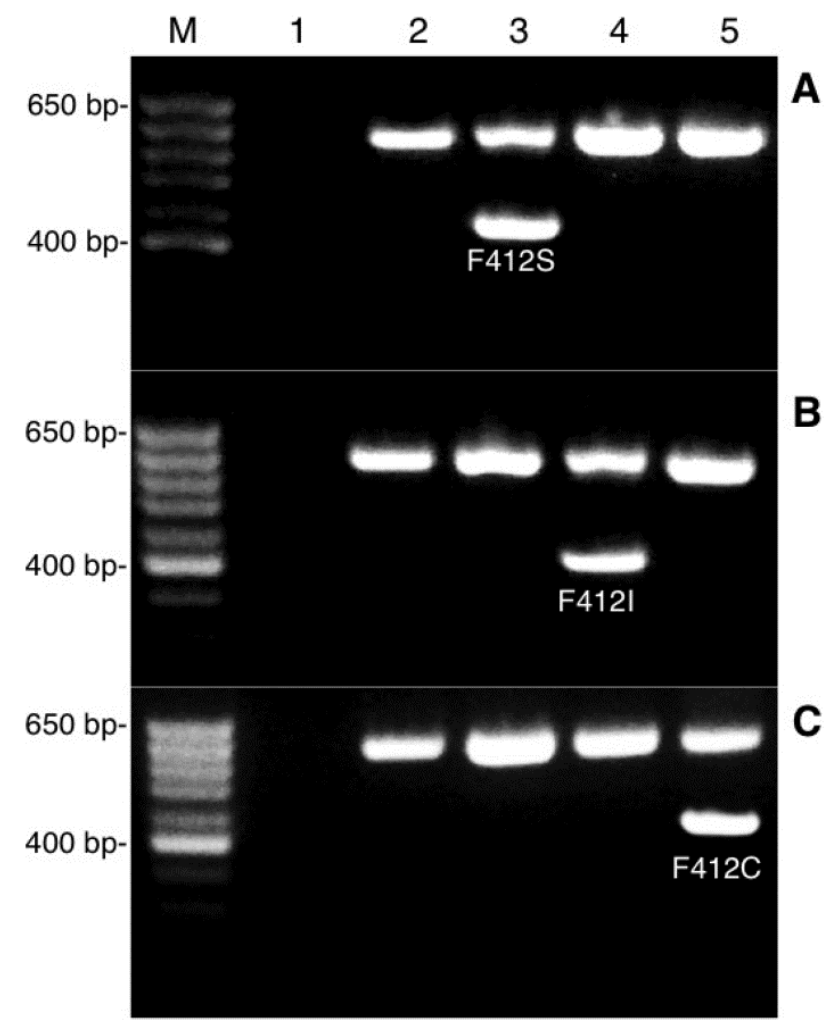

Fig. 4. F412 allele-specific polymerase chain reaction distinguishing the F412S, F412I, and F412C mutations in Botrytis cinerea. Primers A, F412S_int; B, F412I_int; and C, F412C_int in combination with primer F412_F each amplified a 421-bp fragment from isolates SBY11 ${ }^{\mathrm{F} 412 \mathrm{~S}}, \mathrm{NC}^{\mathrm{F}}{ }^{\mathrm{4} 121}$, and SBY20 ${ }^{\mathrm{F} 412 \mathrm{C}}$ (lanes 3-5,

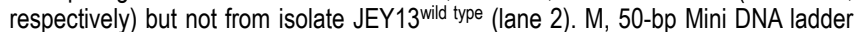
(Fisher Scientific). Products were electrophoresed on 1.8\% agarose gels. resistance were submitted to GenBank (JX436968, JX436969, JX436970, and JX436971).

Development of an assay to screen for erg27 mutations present in fenhexamid-resistant strains in the Carolinas. A multiplex PCR assay able to differentiate between isolates with wildtype codons at T63 and F412, and those with a T63I or F412/S/I/C allele were developed to allow for rapid screening of $B$. cinerea isolates. The assay simultaneously amplifies two regions of the erg27 gene (586 and $584 \mathrm{bp)} \mathrm{from} \mathrm{all} \mathrm{isolates} \mathrm{as} \mathrm{a} \mathrm{positive} \mathrm{control,}$ a 354-bp region primed from the T63 wild-type codon, and a 421bp fragment primed from the F412 wild-type codon. A single, unpredicted, and nonspecific band of about 1,200 bp in size was amplified when using the six-primer PCR cocktail (data not shown). The ability of the assay to differentiate between representative wild-type, T63I, and F412S isolates is shown in Figure 2. The assay also detects isolates with the F412C and F412I alleles (data not shown). An allele-specific PCR assay to discriminate between the F412 alleles was also developed (Fig. 4).

All of the isolates collected in 2011 were subjected to both PCR assays (Table 2). Modifications of F412 were more common than the T63I mutation, and the predominant F412 variation $(n=29)$ was F412S. This mutation was found in all locations where fenhexamid-resistant phenotypes were present. The F412C mutation was observed in three isolates collected from a single location (NC) in North Carolina, whereas the F412I mutation was found in only one isolate at location SBY in North Carolina. The three isolates possessing the T63I mutation were also found at location SBY (Fig. $3)$. Whether these were clonal isolates or whether they derived from different genetic backgrounds was not investigated in this study.

Detached fruit assay. To assess the performance of formulated fenhexamid in vivo against resistant isolates, fruit treated with Elevate $50 \mathrm{WDG}$ at label rates were challenged with $B$. cinerea isolates GIK1, SBY21, NC12, SBY20, and SBY36 carrying the erg27 wild type, T63I, F412C, F412I, and F412S allele, respectively, in detached fruit assays. No treatment-experimental replication, isolate-experimental interaction, or treatment-isolate by experimental interactions (all $P \geq 0.89$ ) were observed and, thus, the data of the independent experimental replications were combined. Gray mold symptoms on the fruit sprayed with distilled sterile water began at the site of inoculation as a small, light-brown lesion which enlarged quickly and became covered with a gray, fuzzy mass of spores after 4 days of inoculation. Field rates of Elevate 50 WDG controlled isolates carrying the erg27 wild-type allele but not isolates carrying either one of the four Erg27 amino acid mutations (F412S, -C, -I, and T63I) (Table 3).

\section{Discussion}

Fenhexamid is one of the most frequently used site-specific fungicides for gray mold control in commercial strawberry fields in the Carolinas and other states in the southeastern United States. This study documents widespread resistance to fenhexamid in the Carolinas based on the presence of fenhexamid-resistant isolates in 7 of 11 strawberry fields sampled. All producers (except the one operating location WIC) indicated having used Elevate for gray

Table 3. Efficacy of Elevate 50WDG treatment on detached strawberry fruit on field isolates of Botrytis cinerea carrying the T63I, F412C, F412I, or F412S mutations $^{\mathrm{z}}$

\begin{tabular}{|c|c|c|c|c|c|c|c|c|}
\hline \multirow[b]{3}{*}{ Isolate } & \multicolumn{6}{|c|}{ Sporulating lesions (\%) } & \multirow{2}{*}{\multicolumn{2}{|c|}{$\begin{array}{c}\text { Lesion size }(\mathrm{cm}) \\
4 \text { dai } \\
\end{array}$}} \\
\hline & \multicolumn{2}{|c|}{2 dai } & \multicolumn{2}{|c|}{3 dai } & \multicolumn{2}{|c|}{4 dai } & & \\
\hline & Control & Elevate & Control & Elevate & Control & Elevate & Control & Elevate \\
\hline GIK $1^{\text {wild type }}$ & $19 a b$ & $0 \mathrm{c}$ & $60 \mathrm{~d}$ & $0 \mathrm{e}$ & $98 \mathrm{a}$ & $5 \mathrm{~b}$ & $2.6 \mathrm{c}$ & $0.1 \mathrm{~d}$ \\
\hline SBY $21^{\mathrm{T} 63 \mathrm{I}}$ & $15 \mathrm{ab}$ & $8 \mathrm{bc}$ & $70 \mathrm{bcd}$ & $65 \mathrm{~cd}$ & $100 \mathrm{a}$ & $100 \mathrm{a}$ & $3.1 \mathrm{ab}$ & $2.8 \mathrm{bc}$ \\
\hline $\mathrm{NC} 12^{\mathrm{F} 412 \mathrm{C}}$ & $17 \mathrm{ab}$ & $8 \mathrm{bc}$ & $88 \mathrm{ab}$ & $79 \mathrm{abcd}$ & $100 \mathrm{a}$ & $100 \mathrm{a}$ & $3.2 \mathrm{ab}$ & $3.0 \mathrm{abc}$ \\
\hline SBY $20^{\mathrm{F} 412 \mathrm{I}}$ & $31 \mathrm{a}$ & $13 \mathrm{ab}$ & $93 \mathrm{a}$ & $85 a b c$ & $100 \mathrm{a}$ & $100 \mathrm{a}$ & $3.5 \mathrm{a}$ & $3.3 \mathrm{ab}$ \\
\hline SBY $36^{\mathrm{F} 412 \mathrm{~S}}$ & $19 a b$ & $13 \mathrm{ab}$ & $69 \mathrm{bcd}$ & $71 \mathrm{bcd}$ & $100 \mathrm{a}$ & $100 \mathrm{a}$ & $3.0 \mathrm{bc}$ & $3.1 \mathrm{ab}$ \\
\hline
\end{tabular}

${ }^{\mathrm{z}}$ Numbers in control and Elevate treatment columns for each days after inoculation (dai) section separately followed by the same letter are not significantly different at $\alpha=0.05$ as determined by analysis of variance. Mean separation was conducted using Student's $t$ test. 
mold disease control, suggesting that producers have selected for resistance over time. By far the highest percentage of resistant isolates was obtained from commercial strawberry field SBY in North Carolina but it is unknown whether this producer used Elevate 50 WDG more frequently compared with others, which would potentially have selected more aggressively for resistant strains. The same location had the greatest diversity of resistance alleles, which may also be an indicator of higher selection pressure, but it is also possible that the genetic diversity was simply higher in this location. Another explanation for the detection of multiple genotypes only in this location may be that the sample size was greater than that of other locations, making it more likely to find infrequent genotypes. Fenhexamid resistance was absent in locations FLOR, MER, MV, and WIC, which might have been a result of lower selection pressure or may have been a consequence of smaller sample sizes (FLOR, MER, and MV represented the lowest sample sizes with 13,3 , and 10 isolates, respectively). The WIC location was the only organic farm we sampled and, thus, Elevate $50 \mathrm{WDG}$ or any other site-specific fungicide was not used there for at least the last 3 years. Therefore, in this location, the absence of selection pressure can explain the absence of resistant genotypes on sampled fruit.

The frequency of fenhexamid-resistant isolates obtained from commercial strawberry fields in North and South Carolina was low ( $16.8 \%$ on average) compared with the frequency in other studies, which may indicate that Carolina populations are still in the early stages of selection for resistance. The overall frequency of fenhexamid-resistant isolates of $B$. cinerea in Californian and Northern German strawberry production areas was 38 and $45 \%$, respectively $(20,27)$. Frequencies of isolates from German and French vineyards highly resistant to fenhexamid varied from less than $30 \%$ to more than $50 \%$ (15), while $35 \%$ of $B$. cinerea isolates from Chilean table grapes were highly resistant (11). Interestingly, all Carolina isolates resistant to fenhexamid were also resistant to the QoI azoxystrobin and the SDHI boscalid (12). This emergence of strains with resistance to multiple fungicides and lack of reduced fitness poses a serious threat to our efforts to manage fungicide resistance in strawberry fields.

As has been found in other Botrytis isolates with high resistance to fenhexamid, mutations in the erg27 gene were present in resistant Carolina isolates. The F412S mutation of Erg27 has been the most common mutation conferring resistance to fenhexamid in B. cinerea populations from strawberry fields in France, Germany, and Chile, and was also the most common mutation found in the Carolinas. Fenhexamid resistance in our isolates was associated with three other amino acid substitutions in the $\operatorname{Erg} 27$ protein (i.e., T63I, F412I, and F412C). Mutations of F412 (F412S, F412I, and F412V) were first observed in field isolates from French and German vineyards (15) and later described in fenhexamid-resistant laboratory mutants (25). The F412S and F412V mutations were also found in Chilean isolates from table grape (11). Proof of association of these mutations with the resistant phenotype was provided using isogenic lines carrying the mutant alleles (5). Two novel alleles, F412C and T63I, were present in our collection. Both are strongly associated with the resistant phenotype because isolates carrying these mutations did not contain any of the other mutations associated with resistance and none of the sensitive isolates had those mutations.

The F412 mutations are located in the carboxylic end of the putative transmembrane domain of the 3-ketoreductase and probably modify the affinity of the 3-ketoreductase for fenhexamid $(5,9)$. For example, a hydrophobic amino acid such as a serine residue at position 412 seems to change the structure of the Erg27 protein, resulting in a decrease in affinity for fenhexamid (5). The variation at amino acid position 63 found in this study for the first time in field isolates was described previously in laboratory mutants resistant to fenhexamid $(9,25)$. This confirms the validity of making and analyzing laboratory mutants in anticipation of such mutants being produced in the field. Amino acid T63 is located in a domain of still unknown function.
Isolates carrying the $\mathrm{T} 63 \mathrm{I}$ or $\mathrm{F} 412 \mathrm{~S} / \mathrm{C} / \mathrm{I}$ mutations displayed not only fenhexamid resistance in vitro but also caused gray mold disease on detached fruit treated with the label rate of Elevate 50 WDG. These results demonstrate the significance of these mutations in commercial strawberry production. A previous study of isogenic strains carrying the F412S, F412I, or F412V found that the mutants grew more slowly in extreme conditions and displayed variations in the production of conidia and susceptibility to freezing (5). However, no significant difference was detected under optimal growth conditions, which is in line with our findings. Taken together, isolates with F412S, F412I, or F412V mutations are likely to successfully compete with wild-type isolates during the fruit production season; however, during winter, strains carrying one of the mutations may experience a disadvantage, which may reduce the frequency of resistant strains in the total population for the next season. Whether these isolates carrying F412S have a competitive advantage in the field compared with other fenhexamid-resistant isolates is not known.

We developed two PCR assays that quickly and reliably distinguish isolates from the Carolinas sensitive or resistant to fenhexamid and that determine the mutation associated with resistance. Billard et al. (6) had previously developed a real-time PCR method called the allele-specific probe and primer amplification assay. This method can quantify the three single-nucleotide polymorphisms resulting in the amino acid substitutions F412S/I/V. However, F412C and T63I cannot be identified with this assay. In addition, a real-time PCR cycler is needed whereas only a standard PCR cycler is required for the two assays developed in this study. The PCR assay developed in this study will be useful to study the prevalence and spread of these specific genotypes in the southeastern United States. However, due to the specificity of the PCR assay for the specific alleles found in this study, the assay may not necessarily be able to detect other potential alleles at these amino acid positions.

In conclusion, fenhexamid resistance is widespread in the Carolinas but most often accounted for only a small percentage of the local population. Interestingly, resistance was, without exception, based on one of four different target site mutations. Our study strongly suggests that fenhexamid resistance in $B$. cinerea needs to be monitored in commercial strawberry fields of the Carolinas. Growers need to implement resistance management strategies such as rotating chemical classes or tank mixing fenhexamid with other products from different chemical classes for gray mold disease management.

\section{Acknowledgments}

This work was supported by the United States Department of Agriculture (USDA) Cooperative State Research, Education and Extension Service under project number SC-1000642 and the USDA Specialty Crops Research Initiative Grants Program number 2010-51181-21113. We thank E. L. Schnabel for helpful comments on preparing this manuscript.

\section{Literature Cited}

1. Albertini, C., and Leroux, P. 2004. A Botrytis cinerea putative 3-keto reductase gene (ERG27) that is homologous to the mammalian $17 \beta$-hydroxysteroid dehydrogenase type 7 gene (17ß-HSD7). Eur. J. Plant Pathol. 110:723733.

2. Albertini, C., Thebaud, G., Fournier, E., and Leroux, P. 2002. Eburicol 14 $\alpha$-demethylase gene (CYP51) polymorphism and speciation in Botrytis cinerea. Mycol. Res. 106:1171-1178.

3. Baroffio, C. A., Siegfried, W., and Hilber, U. W. 2003. Long-term monitoring for resistance of Botryotinia fuckeliana to anilinopyrimidine, phenylpyrrole, and hydroxyanilide fungicides in Switzerland. Plant Dis. 87:662-666.

4. Billard, A., Fillinger, S., Leroux, P., Bach, J., Lanen, C., Lachaise, H., Beffa, R., and Debieu, D. 2011. Fenhexamid resistance in the Botrytis species complex, responsible for grey mould disease. Pages 61-78 in: Fungicides-Beneficial and Harmful Aspects. N. Thajuddin, ed. InTech Publisher, Rijeka, Croatia.

5. Billard, A., Fillinger, S., Leroux, P., Lachaise, H., Beffa, R., and Debieu, D 2012. Strong resistance to the fungicide fenhexamid entails a fitness cost in Botrytis cinerea, as shown by comparisons of isogenic strains. Pest Manage. Sci. 68:684-691.

6. Billard, A., Laval, V., Fillinger, S., Leroux, P., Lachaise, H., Beffa, R., and Debieu, D. 2012. The allele-specific probe and primer amplification assay, a 
new real-time PCR method for fine quantification of single-nucleotide polymorphisms in pooled DNA. Appl. Environ. Microbiol. 78:1063-1068.

7. Chi, M. H., Park, S. Y., and Lee, Y. H. 2009. A quick and safe method for fungal DNA extraction. Plant Pathol. J. 25:108-111.

8. Debieu, D., Bach, J., Hugon, M., Malosse, C., and Leroux, P. 2001. The hydroxyanilide fenhexamid, a new sterol biosynthesis inhibitor fungicide efficient against the plant pathogenic fungus Botryotinia fuckeliana (Botrytis cinerea). Pest Manage. Sci. 57:1060-1067.

9. De Miccolis Angelini, R. M., Pallastro, S., and Faretra, F. 2012. Genetics of fungicide resistance in Botryotinia fuckeliana (Botrytis cinerea). Pages 237250 in: Fungicide Resistance in Crop Protection: Risk and Management. T. $\mathrm{S}$. Thind, ed. CABI, Oxfordshire, UK and Cambridge, MA.

10. De Miccolis Angelini, R. M., Rotolo, C., Pollastro, S., and Faretra, F. 2010. Phenotypic and molecular characterization of fungicide-resistant field isolates of Botryotinia fuckeliana (Botrytis cinerea). Page 46 in: Abstr. Book XV Int. Botrytis Symp. Càdiz, Spain.

11. Esterio, M., Ramos, C., Walker, A.-S., Fillinger, S., Leroux, P., and Auger, J. 2011. Phenotypic and genetic characterization of Chilean isolates of Botrytis cinerea with different levels of sensitivity to fenhexamid. Phytopathol. Mediterr. 50:414-420.

12. Fernández-Ortuño, D., Chen, F., and Schnabel, G. 2012. Resistance to pyraclostrobin and boscalid in Botrytis cinerea isolates from strawberry fields in the Carolinas. Plant Dis. 96:1198-1203.

13. Fernández-Ortuño, D., Li, X., Wang, F., and Schnabel, G. 2011. First report of gray mold of strawberry caused by Botrytis cinerea in South Carolina. Plant Dis. 95:1482.

14. Fernández-Ortuño, D., Li, X., Wang, F., and Schnabel, G. 2012. First Report of gray mold of strawberry caused by Botrytis caroliniana in North Carolina. Plant Dis. 96:914.

15. Fillinger, S., Leroux, P., Auclair, C., Barreau, C., Al Hajj, C., and Debieu, D. 2008. Genetic analysis of fenhexamid-resistant field isolates of the phytopathogenic fungus Botrytis cinerea. Antimicrob. Agents Chemother. 52:3933-3940

16. Forster, H., Su, H., Vilchez, M., Gubler, W., and Adaskaveg, J. E. 2007. Non-persistent captan- and fenhexamid-resistance in Botrytis cinerea populations in California strawberries. (Abstr.) Phytopathology 97:S36.

17. Fournier, E., Giraud, T., Albertini, C., and Brygoo, Y. 2005. Partition of the Botrytis cinerea complex in France using multiple gene genealogies. Mycologia 97:1251-1267.

18. Leroux, P., Fritz, R., Debieu, D., Albertini, C., Lanen, C., Bach, J., Gredt, M., and Chapeland, F. 2002. Mechanisms of resistance to fungicides in field strains of Botrytis cinerea. Pest Manage. Sci. 58:876-888.

19. Li, X., Kerrigan, J., Chai, W., and Schnabel, G. 2012. Botrytis caroliniana, a new species isolated from blackberry in South Carolina. Mycologia. 104:650-658.

20. Mercier, J., Kong, M., and Cook, F. 2009. Prevalence of fungicide resistance in Botrytis cinerea isolates from strawberry fields in California (Abstr.) Phytopathology 99:S84

21. Moorman, G. W., Walker, A.-S., and May, S. 2012. First report of fenhexamid-resistant Botrytis cinerea causing gray mold on Heurchera in a North American greenhouse. Plant Dis. 96:147.

22. Noncitrus fruits and nuts 2011 preliminary summary. National Agricultural Statistics Service, USDA. Retrieved 6 June 2012 from http://usda.mannlib. cornell.edu/MannUsda/viewDocumentInfo.do?documentID=1113

23. Rosslenbroich, H. J., and Stuebler, D. 2000. Botrytis cinerea-history of chemical control and novel fungicides for its management. Crop Prot. 19:557-561.

24. Saito, S., Cadle-Davidson, L., and Wilcox, W. F. 2011. Practical resistance to fenhexamid Botrytis cinerea isolates from grapevines in New York. (Abstr.) Phytopathology 101:S158.

25. Saito, S., Furuya, S., Takayanagi, T., and Suzuki, S. 2010. Phenotypic analyses of fenhexamid resistant Botrytis cinerea mutants. Pages 247-260 in Fungicides. O. Carisse, ed. InTech Publisher, Rijeka, Croatia.

26. Suty, A., Pontzen, R., and Stenzel, K. 1999. Fenhexamid-sensitivity of Botrytis cinerea: determination of baseline sensitivity and assessment of the risk of resistance. Pflanzenschutz Nachr. Bayer (Ger. Ed.) 52:145-157.

27. Weber, R. W. S. 2011. Resistance of Botrytis cinerea to multiple fungicides in Northern German small-fruit production. Plant Dis. 95:1263-1269.

28. Weber, R. W. S., and Hahn, M. 2011. A rapid and simple method for determining fungicide resistance in Botrytis. J. Plant Dis. Prot. 118:17-25. 